\title{
IN-VITRO FREE RADICAL SCAVENGING AND ANTICANCER POTENTIAL OF METHANOL LEAF EXTRACT OF PLANT BACOPA MONNIERI AGAINST HCT15- CELL LINE
}

\author{
Ramachandiran Mangaleshwari \\ Department of Zoology, \\ Thiruvalluvar University, \\ Serkkadu, Vellore-632 115, Tamilnadu, India.
}

\begin{abstract}
It is a universal fact that all living organisms are depending on plants for breathe, food, medicinal and everyday necessities. So, since the period of time immemorial, the peoples are using plant as a medicine to cure various diseases without knowing the scientific back-ground beyond this. The plant Bacopa monnieri (L.) Wettst, comes under the family Scrophulariaceae are commonly known by different names such as Water hyssop, Baby's tear, Brahmi, Jalbrahmi, Nira-brahmi and Saraswati. In Ayurvedic system of ancient civilization, this plant is used to treat anxiety, improving cognitive functions, memory enhancement, hepato-protection and neuroprotection. This practice is continuing even today in the village side. Hence, the present study has been designed to evaluate the phytochemical constituents, extractive value to determine appropriate solvent to get maximum phytocompounds and antioxidant potential of the plant Bacopa monnieri. The obtained results have seen the presence of various important secondary metabolites such as amino acids, steroids, glycosides, flavonoids, alkaloids and tannins in methanolic extract. The Cytotoxicity analysis by the MTT (3-[4,5-dimethylthiazole-2-yl]-2,5diphenyltetrazolium bromide) assay method showed a significant decline in cell viability in the colon cancer cell line-HCT15 indicates the presence of anticancer activity for this plant extract. The anticancer potential of Bacopa monnieri increased with increasing concentrations of plant extract.
\end{abstract}

Key words: Bacopa monnieri (L.), free radical scavenging, anticancer, FTIR, GCMS, DPPH, FRAP, nitrous oxide, Phytocompounds

\author{
Muthiah Chandran \\ Department of Zoology, \\ Thiruvalluvar University, \\ Serkkadu, Vellore-632 115, Tamilnadu, India.
}

\section{INTRODUCTION}

India has a rich culture with good knowledge in usage of medicinal herbs and species. India is one of the 17 megabiodiverse countries in the world. Nearly 50,000-70,000 medicinal plants were reported till date in India which leads to pave a way for very big exposure to traditional medicines such as Ayurvedic, Unani, Siddha from the ancient period. Even today majority of the people in rural India are using plant based traditional medicines to cure the various diseases. But, in this context both the medicinal practitioners and patients are not aware about the chemical constituents of the plant and their disease curing potential. Till date a very few studies were conducted to identifying phytochemical and pharmacological potential to cure the diseases [1-2]. Recently the most of the researchers are involving in phytochemical study on plants to know their phytocompounds constituents, properties and various diseases [3]. Usually, in human being vast majority of diseases are caused by the free radical generation during metabolic processes. The natural defense of the human body against free radicals is not always sufficient mainly due to the significant exposure to pollutant substances. But, the medicinal plants having the rich antioxidants are very helpful to balance the accumulation of free radicals in human body. The plant Bacopa monnieri (L) listed the family Scrophulariaceae, has been used for more 3000 years as Indian Ayurvedic medicines for improving memory, increasing brain function, or promoting longevity [4-6]. Bacopa monnieri is a small creeping plant having numerous branches, fleshy, oblong leaves and small plant. Fruits and flowers are appearing in summer period the whole plant is medicinally important [7]. It is also possesses anti-inflammatory, analgesic, 


\section{International Journal of Engineering Applied Sciences and Technology, 2020 \\ Vol. 5, Issue 4, ISSN No. 2455-2143, Pages 300-309 \\ Published Online August 2020 in IJEAST (http://www.ijeast.com)}

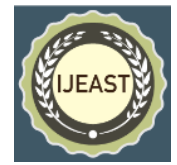

antipyretic, epilepsy, insanity, anticancer and antioxidant activities [8-11]. In addition, the plant has been recommended as an agent for phytoremediation [12-15]. Hence, the in present investigation has been programmed to evaluate the qualitative of phytochemical analysis, extractive value and antioxidant potential of Bacopa monnieri.

\section{MATERIALS AND METHOD}

\begin{abstract}
$A$. Collection of plant material and authenticationThe whole plant of Bacopa monnieri (L) was collected from Nowlock garden, Avaraikkarai village, Ranipet area, Vellore District, Tamil Nadu, India. The plant sample was identified and authenticated by Institute of herbal science, Plant anatomy research Centre, Chennai, Tamil Nadu. The identification specimen number is (PARCl17\3535). The leaves were alone handpicked from plant and washed with distilled water to remove dust and other small insects stick on it. The cleaned leaves were dried for 30 days at room temperature $\left(32^{\circ} \mathrm{C}\right)$ in shade place to avoid the loss of vitamins and denature of phytocompounds. After the completion of drying process, the shade dried leaves were powdered coarsely using electric blender. Then the powder was stored into air tight container for future uses.
\end{abstract}

\section{$B$. Determination of Extractive value-}

The dry Bacopa monnieri plant powder was extracted in different solvents such as water, methanol, ethanol, ethyl acetate, chloroform, petroleum ether and hexane by using the maceration process. For this study, accurately $1 \mathrm{gm}$ of plant powder was taken in a small beaker $(100 \mathrm{ml})$ and $50 \mathrm{ml}$ of any one of above mentioned desired solvent was mixed with it. The entire setup was kept at room temperature for 24 hours. The mixture was shacked frequently. Thereafter, the extract was filtered using No.1 Whatmann filtered paper [16]. The filtrate was shifted to pre-weighed petri plates. Date and weight of the plate it were marked. The extract was kept upto complete evaporation of solvent. Finally, the dried extract containing petri plates was weighed. The extractive value (\%) was calculated used by following formula.

Extractive value (\%) $=$ Weighed dried extract/ Weigh of plant material X 100

\section{$C$. Preparation of the plant extract}

Bacopa monnieri plant powder $20 \mathrm{gm}$ was packed in a thimble and $200 \mathrm{ml}$ of methanol solvent was filled in the bottom of soxhlet. The heating mantle was set at $60^{\circ} \mathrm{C}$ [17]. After the completion of extraction, the methanolic leaf extract collected on the bottom were concentrated by evaporating it to dryness under reduced pressure by rotary vacuum evaporator to obtain the dried sample. The sample was stored at $180^{\circ} \mathrm{C}$ for further analysis.

\section{Preliminary Qualitative phytochemical determination}

The methanolic plant extract obtain from soxhlation process were subjected to preliminary qualitative determination for the presence of phytocompounds such as cardio glycosides, alkaloids, flavonoids, saponins, phenols, steroids, Proteins, Anthraquinones, coumarin, triterpenes, quinines and tannins by standard methods [18].

\section{i. Test for tannins:}

The methanol leaf extract of the plant Bacopa monnieri was taken in three separate test tubes. In each test tube few drops of $0.1 \%$ ferric chloride were added. The brownish green or blue black colour was formed in test tube indicates the presence of tannin.

\section{ii. Test for saponins:}

$1 \mathrm{ml}$ of leaf extract and $2 \mathrm{ml}$ of water was taken in a test tube. This mixture was shaken 15 minutes. A layer of foam is appeared. The appearance of foam layer indicates the presence of saponins.

\section{iii. Test for flavonoids:}

$1 \mathrm{ml}$ of methanolic plant leaf extract was taken in test tube. Addition to this $1 \mathrm{ml}$ of $\mathrm{NaOH}$ was added. Now, the yellow colour formation in test tube formed into white colour after adding few drops of con. $\mathrm{H}_{2} \mathrm{SO}_{4}$ confirmed the presence of flavonoids.

\section{iv. Test for alkaloids: \\ Drangandroff reagent}

$1 \mathrm{ml}$ of Bacopa monnieri plant extract was taken along with, few drops of drangandroff reagent was added. A prominent yellow colour precipitates was formed in a test tube. It indicates presence of alkaloids as positive.

\section{Mayer's test}

Take $1 \mathrm{ml}$ of plant extract in a test tube. Along with few drops of Mayer's reagent were added. The white creamy was observed indicates the presence of alkaloid.

\section{Wagner's test}

Methanolic leaf extract was taken in a test tube, along with few drops of Wagner's reagent were slowly added. Creamish brown colour precipitate in a test tube confirmed the presence of alkaloids.

\section{v. Test for protein:}

$1 \mathrm{ml}$ of sample was taken. Along with few drops of Millon's reagent was added. Appearing of white 


\section{International Journal of Engineering Applied Sciences and Technology, 2020 \\ Vol. 5, Issue 4, ISSN No. 2455-2143, Pages 300-309 \\ Published Online August 2020 in IJEAST (http://www.ijeast.com)}

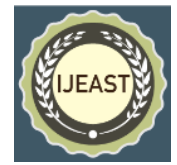

precipitate in the test tube indicates the presence of Protein.

\section{vi. Test for steroids:}

$1 \mathrm{ml}$ of Bacopa monnieri plant extract was taken in a test tube, along with two drops of $10 \%$ concentrated sulphuric acid was added and observed for brown colour. Formation of characteristic the brown colour precipitate indicates the presence of steroids.

\section{vii. Test for anthraquinones:}

$1 \mathrm{ml}$ of plant extract was taken in a test tube along with aqueous ammonia solution was added and observed for colour changes in a test tube. Appearing of pink colour in aqueous layer confirmed the presence of anthraquinoness.

\section{viii. Test for phenols:}

$1 \mathrm{ml}$ crude plant extract was taken in a test tube. After that $3 \mathrm{ml}$ of $10 \%$ lead acetate solution was added. The bulk white colour precipitate formed at the surface indicates the presence of phenolic compounds.

\section{ix. Cardio glycosides:}

$1 \mathrm{ml}$ of plant extract was taken in a test tube, along with $1 \mathrm{ml}$ of glacial acetic acid, $1 \mathrm{ml}$ of ferric chloride few drops of concentrated sulphuric acid was added. The appearance of reddish brown at the junction of the 2 liquid layers indicates presence of cardio glycosides.

\section{x. Coumarin:}

$2 \mathrm{ml}$ of $10 \%$ sodium hydroxide was added to $2 \mathrm{ml}$ of plant extract. Formation of yellow colour in the test tube indicates presence of coumarins.

\section{xi. Triterpenes:}

$2 \mathrm{ml}$ of methanolic leaf extract was taken along with few drops concentrated sulphuric acid was added. The formation of reddish brown ring in a test tube indicates the presence of Triterpenes.

\section{xii. Quinines:}

$1 \mathrm{ml}$ of plant extract was taken in a test tube, along with $1 \mathrm{ml}$ of $1 \%$ sodium hydroxide were added and mixed well. The appearance of dark blue green indicates confirmed the presence of quinines.

\section{FTIR analysis}

Functional groups of phytochemicals present in the plant were identified by using the powerful tool FTIR. The FTIR model Jasco was used in this study. For this study $5 \mathrm{mg}$ of dried fine plant powder was taken and mixed with $50 \mathrm{mg}$ of kbr to make a pellet. This pellet was loaded in the FTIR and scan at room temperature in the spectral ranges from $400-4000 \mathrm{~cm}^{-1}$. The results obtain from the
FTIR were interpreted by analysed the chemical bonds for particular peak value.

\section{E. TLC}

5 gram dried leaf powder of Bacopa monnieri was taken in a conical flask. Along with $10 \mathrm{ml}$ of methanol was added. This setup was kept in magnetic sterrier for 1 day to obtain complete dissolving of phytocompounds of leaf in the methanol solvent. The extract obtained from this maceration process was filtered through No.1. Whattman filter paper. The appropriate solvent system chosen for the present study was composed of methanol: chloroform: hexane (14:4:2). The silica gel precoated readymade aluminum plate obtained from Harish Scientific Company in Vellore used as a stationary phase. Thereafter $5 \mu \mathrm{l}$ of sample was spotted on the marked place on TLC plate and allowed to run in a TLC chamber saturated with the mobile phase of solvents. Then the spot of antioxidant activity was qualitatively screened by dipping the TLC plates down for 10 seconds in $0.5 \mathrm{~mm}$ in DPPH solution. The chromatogram of TLC turned into purple colour due to the presence of antioxidant activity.

\section{$F$. Antioxidant assays \\ i. Determination of DPPH scavenging assay:}

The DPPH (2,2-diphenyl-1-picrylhydrazyl) free radical scavenging antioxidant activity of plant extract was determined by the method followed Blois [19]. An aliquot amount of $0.5 \mathrm{ml}$ methanolic leaf extract of Bacopa monnieri was taken in a test tube, along with 2.5 $\mathrm{ml}$ of $0.5 \mathrm{~mm}$ methanolic solution of DPPH was added. The sample mixture was shaken vigorously and incubated for $30 \mathrm{~min}$ in the dark place at room temperature. Thereafter the colour of the solution was measured by using UV spectrophotometer at $517 \mathrm{~nm}$ (triplicate values). The ascorbic acid was used for a positive control. The scavenging activity of the plant extract was calculated by using the following formula and expressed in a unit $\%$ of inhibition.

$\%$ of inhibition $=$ Absorbance of control - Absorbance of sample/Absorbance of control X 100.

\section{ii. FRAP Assay}

The ferric reducing power of Bacopa monnieri methanolic leaf extract were determined by using FRAP method [20-21]. This reaction is based on the reduction of colorless ferric complex ( $\mathrm{Fe}^{3+}$ tripyridyltriazine) to blue-colored ferrous complex $\left(\mathrm{Fe}^{2+}\right.$ tripyridyltriazine) by the action of electron donating antioxidants at low $\mathrm{pH}$. The reduction was monitored by measuring the change of absorbance at $593 \mathrm{~nm}$. The working FRAP reagent was prepared by mixing 10 volumes of $300 \mathrm{mM}$ acetate buffer, $\mathrm{pH} 3.6$, with 1 volume of $10 \mathrm{mM}$ TPTZ $(2,4,6-$ tri(2-pyridyl)-striazine) in $40 \mathrm{~m} \mathrm{Mm} \mathrm{HCl}$ and with 1 
volume of $20 \mathrm{mM}$ ferric chloride. All the required solutions were freshly prepared just before use. $100 \mu \mathrm{L}$ of samples $(\mathrm{mg} / \mathrm{mL})$ were added to $3 \mathrm{~mL}$ of prepared FRAP reagent. The reaction mixture was incubated in a water bath for $30 \mathrm{~min}$ at $37 \circ \mathrm{C}$. The standard curve of ferric chloride $(125 \mu \mathrm{mol}, 250 \mu \mathrm{mol}, 500 \mu \mathrm{mol}, 750 \mu \mathrm{mol}$ and $1000 \mu \mathrm{mol})$ was prepared using by same procedure. Then, the absorbance of the samples was measured at 593 $\mathrm{nm}$. The difference between absorbance of sample and the absorbance of blank were calculated to determine the FRAP value. FRAP value was expressed in terms of Mmol Fe2+/g of sample using ferric chloride standard curve $\mathrm{Y}=1.7057 \mathrm{x}-0.2211, \mathrm{R} 2=0.9904$.

\section{iii. Nitric oxide radical scavenging activity}

The nitric oxide radical scavenging was measured by Griess reaction [22]. For this experiment, the reaction mixture (3ml) containing sodium nitroprusside $10 \mathrm{mM}$ in phosphate buffered saline was mixed with various concentrations of methanolic plant extract and incubated at $25^{\circ} \mathrm{C}$ for 2.5 hours. After the completion of incubation, $0.5 \mathrm{ml}$ aliquot amount of Griess reagent $[1 \%$ sulfanilamide, 2\% $\mathrm{H} 3 \mathrm{Po} 4$ and $0.1 \% \mathrm{~N}$ - (1-napthyl) ethylene diamine dihydrochloride] was added. Finally, the chromaphore formed in the reaction was measured immediately at $546 \mathrm{~nm}$. The inhibition of nitrate formation by the plant extract and the standard antioxidant ascorbic acid were calculated relative to the nitric oxide radical control. The experiment was triplicated and the percentage of scavenging activity was estimated with Curcumin standard reference.

\section{G. Cytotoxicity of methanol leaf extract of Bacopa monnieri on Colon cancer cell line-HCT15}

Cytotoxicity analysis was done by the MTT (3-[4,5dimethylthiazole-2-yl]-2,5-diphenyltetrazoliumbromide) assay method. Working principles of this method is based on the conversion of MTT into formazan crystals by living cells contain $\mathrm{NAD}(\mathrm{P}) \mathrm{H}-$ dependent oxidorectase enzyme. This assay technology has been widely adopted and remains popular in academic labs to find homogeneous cell viability. The MTT substrate is prepared in a physiologically balanced solution, which has added to culture at a final concentration of 0.2 $0.5 \mathrm{mg} / \mathrm{ml}$, and incubated for 1 to 4 hours. The formazan crystals formed in the cell culture were then dissolved using solubility solution and absorbed at $570 \mathrm{~nm}$ using a plate reading spectrophotometer. The darker solution means the greater the viable and metabolically active cells. The Colon cancer cell line (HCT15) was placed in 96 well plates containing DMEM media with $1 \mathrm{X}$ Antibiotic Antimycotic solution and $10 \%$ fetal bovine serum (Himedia, India). Along with different concentration of methanol leaf extract of Bacopa monnieri were added. Before that, the concentration of cells was determined to $1 \times 10^{-}$cells/well. Then the cell line was incubated in $\mathrm{CO}_{2}$ incubator at $37^{\circ}$ with $5 \% \mathrm{CO}^{2}$. After incubation, the cell line was washed with $200 \mu \mathrm{l}$ of 1X PBS, and MTT reagents were added to each well. The MTT reagent $5 \mathrm{ml}$ containing 5 vials purchase from Sigma Company was used for this experiment. In the present study, this MTT assay method was used to measure the cytotoxicity of plant extract on necrosis of cancer cells in colon.

\section{RESULTS \& DISCUSSION}

The extractive value for Bacopa monnieri leaf was estimated using different solvents and the obtained results were recorded in Table-2 and depicted in Fig.1 (a and b) which showed that the highest yield of extractive value obtained for both methanol $(4.9 \mathrm{gm})$ and water (3.6gm) compared all six solvents. The extractive values of other solvents were observed following sequences ethanol $(2.2 \mathrm{gm})>$ ethyl acetate $(2 \mathrm{gm})>$ chloroform $(0.9 \mathrm{gm})>$ hexane $(1.7 \mathrm{gm})>$ petroleum ether $(0.6 \mathrm{gm})$. Hence the high extractive methanol solvent was selected to extract the phytocompounds from Bacopa monnieri. This result showed a concordance with the findings suggested by [23] that the solvents methanol and acetone appeared to be more effective in extracting bioactive compounds from Mentha viridis. 50\% acetone is an ideal solvent to extract the phenol from Salacia chinensis [24].

Plant based antioxidants play a vital role even in trace amount, is capable of preventing of delaying the oxidation of easily oxidizable materials and emerged as a potential therapeutic to prevent free radical generated damage in the human body [25], flavonoids and phenolic [26]. It acts as reductants and inactivators of oxidants [27]. Most of the plants traditionally used to treat various because of having rich antioxidant which are in the form of phytocompounds such as tannins, flavonoids, alkaloids, steroids, etc. Flavonoids present in dietary sources such as tea, red wine, apple tomato, cherry, anion, thyme, parsley, soya-beans and other legumes in the form of flavonols, flavones, isoflavones and flavonones [28]. The preliminary qualitative phytochemical analysis of leaf of methanol extract of plant Bacopa monnieri has been exhibited the presence of various bioactive compounds such as tannins, saponins alkaloids, steroids, flavonoids proteins, cardioglycolysis and triterpens (Table-1) as similar as with the qualitative analysis of the plant Ephedra intermedia showed the phytocompounds cardioglycocides, alkaloids, reducing sugars, flavonoids, phenols (Ethanol, methanol) [29], phenols and saponins in the methanol extracts of leaves and flowers; alkaloids, flavonoids, terpinoids, carbohydrates, protein and amino acids are present in methanolic extract of leaves, roots and flowers of 


\section{International Journal of Engineering Applied Sciences and Technology, 2020 Vol. 5, Issue 4, ISSN No. 2455-2143, Pages 300-309 \\ Published Online August 2020 in IJEAST (http://www.ijeast.com)}

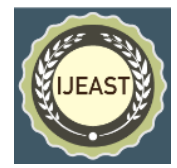

Moringa concansis [30], steroids, alkaloids, cyanide-I mild concentrations in Senna mimosoides. Saponin, phenols, flavonoids, terenoids, soluble carbohydrate and tannins [31]; carbohydrate, amino acids, phenols and alkaloids in the flowers of Bauhina acuminate [32]; alkaloids, terpinoids, steroids, flavonoids, polyphenols, glycosides, tannin and saponins in Acanthopora spicfera and Sargasum wightii [33]; alkaloids, terpenoids, steroid, tannins, flavonoids, phenols, coumarins, quinons and glycosides in the brown seaweed Dictota dichotoma [34]; tannins, saponins, flavonoids, cardioglycides and alkaloids in the crude extract of Ephedra altissima aquous and extract of leaf of Ephedra altissima [35]; cardioglycocides, alkaloids in the stem and fruit, flavonoids present in the leaf of Cissus quadrangularis [36]. After confirmation, the free radical scavenging ability of this plant leaves were determined by observing DPPH, FRAP, Nitric oxide scavenging activities. Even though a number of methods have been proposed to determine the antioxidant activity, in the present investigation a widely used method [37-38] is used to evaluate the free radical scavenging activity and antioxidant activities of plant extracts.

The leaf extract of Bacopa monnieri has the ability to scavenge $72.38 \%$ of DPPH at $250 \mathrm{mg}$ concentration as similar as exhibited (71.18\%) in methanol extracts of the stem of C. africana $(89.69 \%)$ and leaves $(64.95 \%)$ at $0-1$ $\mu \mathrm{g} / \mathrm{ml}$ and $82.58 \%$ of activity at $500 \mu \mathrm{g} / \mathrm{ml}$ [39]. The overall observation of DPPH scavenging activities in the leaf powder of Bacopa monnieri has an increasing trend when concentration is increase. Therefore, the free radical scavenging activities of Bacopa monnieri leaf directly proportionate to their concentration. Nitric oxide (NO) is an important chemical mediator generated by endothelial cells, macrophages, neurons, etc. which is involved in the regulation of various physiological processes [40]. NO is generated in biological tissues by specific nitric oxide synthesis (NOSs), which metabolizes arginine to citralline with the formation of NO via a five electron oxidative reaction [41]. Nitric oxide or reactive nitrogen species, formed during their reaction with oxygen or with superoxides, such as $\mathrm{NO}_{2}, \mathrm{~N}_{2} \mathrm{O}_{4}, \mathrm{~N}_{3} \mathrm{O}_{4}$, $\mathrm{NO}_{3}$ and $\mathrm{NO}_{2}$ are very reactive. These compounds are responsible for altering the structural and functional behavior of many cellular components. The experimentation on scavenging activity of phytocompounds of Bacopa monnieri is very important because of its neuroprotection activities. Fresh leaf extract of Ixora coccinea, showed $49.43 \%$ and $72.18 \%$ NO scavenging, dry flower extract showed $59.43 \%$ and $66.93 \%$ of NO inhibition and fresh flower has $69.45 \%$ and $77.24 \%$ of NO inhibition. FRAP assay was used by several authors for the assessment of antioxidant activity of various food product samples [42-43]. Like DPPH and
Nitric oxide, the same trend of FRAP scavenging activities was observed (Ferric reducing ability of plasma), (Table-3 Fig.2(a, b and c). This results showed some similarity with the antioxidant activities of five Salvia species such as Salvia multicaulis, Salvia verticellata, Salvia lechnecelyx, Salvia mirzayanii and Salvia macrosiphon [44].

The FTIR analysis made on methanol, ethanol, hexane, chloroform and petroleum ether leaf extract of Baccopa monnieri have $11,18,12,14$ and 19 peaks respectively. The extraction of leaf of Baccopa monnieri in all solvents such as ethanol, hexane, chloroform and petroleum ether except the methanol showed bands at 430.26(ethanol), 433.50(hexane), 420.56(Chloroform) and 407.62, 72.32 and 549.96(petroleum ether) $\mathrm{cm}^{-1}$ with $\mathrm{C}-1$ stretching indicate the presence of halo compounds. The band at 572.60 (methanol), 769.94(ethanol), 608.19(chloroform,) 653.48 and 889.64(petroleum ether) would be due to $\mathrm{C}_{-}$ $\mathrm{Br}$ stretch, $\mathrm{C}-\mathrm{H}$ bend indicate the presence of Alkyl halides and Alkynes. The band absorbed at 931.70(methanol), 902.58(ethanol), 909.05(hexane), 931.70(Chloroform) and 993.17(petroleum ether) due to $\mathrm{O}-\mathrm{H}$ bend of carboxylic acids. 1122.57(methanol), 1035.22, 1187.27 and 1264.91(ethanol), 1077.28 and 1287.56(hexane), 1064.34 and 1196.98(Chloroform) and 1109.63(petroleum ether) due to $\mathrm{C}-\mathrm{N}$ stretch indicate the presence of aliphatic amines. 1407.26 and 1501.07(methanol), 1339.32, 1452.55 and 1530.19(ethanol), 1420.20 and 1497.84(hexane), 1309.26, 1393.31 and 1501.07(Chloroform) and 1326.38, 1404.02 and 1478.43 (petroleum ether) due to $\mathrm{N}-\mathrm{O}$ symmetric stretch, $\mathrm{C}-\mathrm{C}$ stretch (in-ring) indicate the presence of Nitro compounds, aromatics. 1653.12(methanol), 1624.01(ethanol), 1633.71(Chloroform) and 1649.89(petroleum ether) due to $\mathrm{N}-\mathrm{H}$ bend indicate the presence of amines. 1824.58(methanol), 1701.65 and 1841.88(ethanol), 1782.53(hexane), 1824.58(Chloroform) and 1772.82(petroleum ether) due to $\mathrm{C}=\mathrm{O}$ bend and indicate the presence of Esters, Anhydrides. 2034.86(methanol) due to $\mathrm{C} \equiv \mathrm{C}$ Stretch indicate the presence of Alkynes (monosubst). 2856.57(methanol), 2914.80(ethanol), 2882.45 and 2940.69(hexane), 2924.51(Chloroform) and 2798.34, 2843.63 and 2930.98(petroleum ether) due to $\mathrm{CH}_{3}$ and $\mathrm{CH}_{2}, \mathrm{C}-\mathrm{H}$ stretch indicate the presence of Alkanes, Aliphatic compounds. 3086.26(ethanol), 3015.09(hexane), 3002.15(Chloroform) and 3015.09 (petroleum ether) due to $=\mathrm{C}-\mathrm{H}$ stretch indicate the presence of Alkenes. 3456.57(methanol), 3429.18 and 3464.77(ethanol), 3358.01(hexane), 3419.48(Chloroform) and 3432.42(petroleum ether) due to $\mathrm{N}-\mathrm{H}$ stretch, $\mathrm{O}-\mathrm{H}$ stretch indicate the presence of Amines or Alcohols. 3875.62(methanol), 3940.33 and 3998.56(ethanol), 3946.80(hexane), 
3742.99(Chloroform) and 3742.99 and 3979.15(petroleum ether) due to $-\mathrm{OH}$ stretch indicate the presence of Alcohols and Phenols.

The screening of plant extract for cytotoxicity on colon cancer cell line of In-vitro study showed a significant level of decline in cell viability (Table.4 and Fig 3). These declining trends were increased in increasing concentration. This means the death of colon cancer cells are increasing with increasing concentration of plant extract which indicate the leaf extract of Bacopa monnieri possess potent anticancer activities. The present study results showed a strong affinity with Rosa anina extract exhibited a selective cytotoxic effect on colon cancer cells compared with normal colon cells. The extract induced cell cycle arrest at the S-phase and apoptosis via reduced MMP in WiDr cells. Rosa canina extract significantly repressed telomerase expressions at treatment times of 48 and $72 \mathrm{~h}$ in WiDr cells [45]. Aerial, leaf and stem extracts of plant Alternanthera sessilis greatly suppressed the growth of colon cancer cells in time and dosage-dependent manner. The cytotoxicity results were rationalized with clonogenic, cell motility and AO/PI assay, where the leaf extract showed the most active activity compared to aerial and stem extracts. [46]. The ethanolic root extract of Euphorbia tehranica showed a significant ctotoxic effect against Caco-2-cell line ( $\mathrm{p} \leq 0.05)$. The viability of Caco-2 cells reduced with the dose and time depentant manner [47].

Table-1. List of phytochemicals present in solvent extract of Bacopa monnieri

\begin{tabular}{|l|l|l|}
\hline $\begin{array}{l}\text { S.N } \\
\text { o }\end{array}$ & $\begin{array}{l}\text { Phytochemical } \\
\text { tests }\end{array}$ & $\begin{array}{l}\text { Methan } \\
\text { ol }\end{array}$ \\
\hline 1. & Tannins & + \\
\hline 2. & Saponins & + \\
\hline 3. & Phenols & - \\
\hline 4. & Alkaloids & + \\
\hline 5. & Coumarin & - \\
\hline 6. & Steroids & + \\
\hline 7. & Anthraquinones & - \\
\hline 8. & Flavonoids & + \\
\hline 9. & $\begin{array}{l}\text { Cardio } \\
\text { glycosides }\end{array}$ & + \\
\hline 10. & Proteins & + \\
\hline 11. & Triterpenes & + \\
\hline 12. & Quinines & - \\
\hline & & \\
\hline
\end{tabular}

Table-2. The extractive value of using different solvents and their dry weight Bacopa monnieri

\begin{tabular}{|c|c|c|}
\hline Solvents & $\begin{array}{c}\text { Dry } \\
\text { weight } \\
\text { of raw } \\
\text { leaf } \\
\text { powder }\end{array}$ & $\begin{array}{c}\text { \% of } \\
\text { extractive } \\
\text { value }\end{array}$ \\
\hline Water & 1 & 3.6 \\
\hline Methanol & 1 & 4.9 \\
\hline Ethanol & 1 & 2.2 \\
\hline $\begin{array}{c}\text { Petroleum } \\
\text { ether }\end{array}$ & 1 & 0.6 \\
\hline Chloroform & 1 & 0.9 \\
\hline Hexane & 1 & 1.7 \\
\hline $\begin{array}{c}\text { Ethyl } \\
\text { acetate }\end{array}$ & 1 & 2 \\
\hline
\end{tabular}

Table-3. Free radical scavenging activities of Bacopa monnieri at different concentration

\begin{tabular}{|l|l|l|l|}
\hline \multicolumn{4}{|c|}{ Free radical scavenging activities } \\
\hline $\begin{array}{l}\text { Different } \\
\text { concentration } \\
\text { of leaf extract } \\
\text { mg }\end{array}$ & DPPH & FRAP & $\begin{array}{l}\text { Nitric } \\
\text { oxide }\end{array}$ \\
\hline $\mathbf{5 0}$ & $23.89 \pm 0.81$ & $34.76 \pm 0.17$ & $12.31 \pm 0.81$ \\
\hline $\mathbf{1 0 0}$ & $39.47 \pm 0.5$ & $40.05 \pm 0.02$ & $27.45 \pm 0.98$ \\
\hline $\mathbf{1 5 0}$ & $59.98 \pm 0.69$ & $42.43 \pm 0.06$ & $41.62 \pm 0.98$ \\
\hline $\mathbf{2 0 0}$ & $66.16 \pm 0.50$ & $46.78 \pm 0.07$ & $62.09 \pm 1.31$ \\
\hline $\mathbf{2 5 0}$ & $72.38 \pm 0.56$ & $51.50 \pm 0.02$ & $73.42 \pm 0.82$ \\
\hline
\end{tabular}

Table-4. Colon cancer cell line different concentration of Bacopa monnieri

\begin{tabular}{|r|l|}
\hline $\begin{array}{l}\text { Tested } \\
\text { concentration }(\boldsymbol{\mu g} / \mathbf{m l})\end{array}$ & $\begin{array}{l}\text { \% of cell } \\
\text { viability }\end{array}$ \\
\hline 25 & $97.74 \pm 2.25$ \\
\hline 50 & $90.21 \pm 2.33$ \\
\hline 100 & $79.57 \pm 1.59$ \\
\hline 250 & $67.63 \pm 3.18$ \\
\hline 500 & $53.33 \pm 3.42$ \\
\hline Control & 100 \\
\hline
\end{tabular}

Table-5. FTIR analysis of the plant Bacopa monnieri in different solvents 
International Journal of Engineering Applied Sciences and Technology, 2020

Vol. 5, Issue 4, ISSN No. 2455-2143, Pages 300-309

Published Online August 2020 in IJEAST (http://www.ijeast.com)

\begin{tabular}{|c|c|c|c|c|c|c|}
\hline \multicolumn{5}{|c|}{ Solvents } & \multirow[t]{2}{*}{ Bonding } & \multirow{2}{*}{$\begin{array}{c}\text { Functional } \\
\text { Group }\end{array}$} \\
\hline $\begin{array}{c}\text { Methan } \\
\text { ol }\end{array}$ & Ethanol & Hexane & $\begin{array}{c}\text { Chlorof } \\
\text { orm }\end{array}$ & $\begin{array}{c}\text { Petrole } \\
\text { um } \\
\text { ether }\end{array}$ & & \\
\hline- & 430.26 & 433.50 & 420.56 & $\begin{array}{l}407.62 \\
472.32 \\
549.96\end{array}$ & $\begin{array}{l}\text { C-l } \\
\text { stretching }\end{array}$ & $\begin{array}{l}\text { Halo } \\
\text { Compounds }\end{array}$ \\
\hline 572.60 & 769.94 & & 608.19 & $\begin{array}{l}653.48 \\
889.64\end{array}$ & $\begin{array}{l}\mathrm{C}-\mathrm{Br} \\
\text { stretch, } \\
\mathrm{C}-\mathrm{H} \\
\text { bend }\end{array}$ & $\begin{array}{l}\text { Alkyl } \\
\text { Halides, } \\
\text { Alkynes, }\end{array}$ \\
\hline 931.70 & 902.58 & 909.05 & 931.70 & 993.17 & $\mathrm{O}-\mathrm{H}$ bend & $\begin{array}{l}\text { Carboxylic } \\
\text { Acids }\end{array}$ \\
\hline 1122.57 & $\begin{array}{l}1035.22 \\
1187.27 \\
1264.91\end{array}$ & $\begin{array}{l}1077.28 \\
1287.56\end{array}$ & $\begin{array}{l}1064.34 \\
1196.98\end{array}$ & 1109.63 & $\begin{array}{l}\mathrm{C}-\mathrm{N} \\
\text { stretch }\end{array}$ & $\begin{array}{l}\text { Aliphatic } \\
\text { Amines }\end{array}$ \\
\hline $\begin{array}{l}1407.26 \\
1501.07\end{array}$ & $\begin{array}{l}1339.32 \\
1452.55 \\
1530.19\end{array}$ & $\begin{array}{l}1420.20 \\
1497.84\end{array}$ & $\begin{array}{l}1309.26 \\
1393.31 \\
1501.07\end{array}$ & $\begin{array}{l}1326.38 \\
1404.02 \\
1478.43\end{array}$ & $\begin{array}{l}\mathrm{N}-\mathrm{O} \\
\text { symmetric } \\
\text { stretch, } \\
\mathrm{C}-\mathrm{C} \\
\text { stretch } \\
\text { (in-ring) }\end{array}$ & $\begin{array}{l}\text { Nitro } \\
\text { Compounds, } \\
\text { Aromatics }\end{array}$ \\
\hline 1653.12 & 1624.01 & & 1633.71 & 1649.89 & $\mathrm{~N}-\mathrm{H}$ bend & Amines \\
\hline 1824.58 & $\begin{array}{l}1701.65 \\
1841.88 \\
\end{array}$ & 1782.53 & 1824.58 & 1772.82 & $\mathrm{C}=\mathrm{O}$ & $\begin{array}{l}\text { Esters, } \\
\text { Anhydrides }\end{array}$ \\
\hline 2034.86 & & & & & $\begin{array}{l}\mathrm{C} \equiv \mathrm{C} \\
\text { Stretch }\end{array}$ & $\begin{array}{l}\text { Alkynes } \\
\text { (Monosubst) }\end{array}$ \\
\hline 2856.57 & 2914.80 & $\begin{array}{l}2882.45 \\
2940.69\end{array}$ & 2924.51 & $\begin{array}{l}2798.34 \\
2843.63 \\
2930.98\end{array}$ & $\begin{array}{l}\mathrm{CH}_{3} \text { and } \\
\mathrm{CH}_{2} \text {, } \\
\mathrm{C}-\mathrm{H} \\
\text { stretch }\end{array}$ & $\begin{array}{l}\text { Alkanes, } \\
\text { Aliphatic } \\
\text { Compounds }\end{array}$ \\
\hline & 3086.26 & 3015.09 & 3002.15 & 3015.09 & $\begin{array}{l}=\mathrm{C}-\mathrm{H} \\
\text { stretch }\end{array}$ & Alkenes \\
\hline 3456.57 & $\begin{array}{l}3429.18 \\
3464.77\end{array}$ & 3358.01 & 3419.48 & 3432.42 & $\begin{array}{l}\mathrm{N}-\mathrm{H} \\
\text { stretch, O- } \\
\text { H stretch }\end{array}$ & $\begin{array}{l}\text { Amines or } \\
\text { Alcohols }\end{array}$ \\
\hline 3875.62 & $\begin{array}{l}3940.33 \\
3998.56\end{array}$ & 3946.80 & 3742.99 & $\begin{array}{l}3742.99 \\
3979.15\end{array}$ & $\begin{array}{l}-\mathrm{OH} \\
\text { stretch }\end{array}$ & $\begin{array}{l}\text { Alcohols and } \\
\text { Phenols }\end{array}$ \\
\hline
\end{tabular}

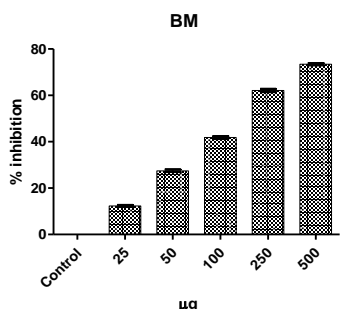

(c)

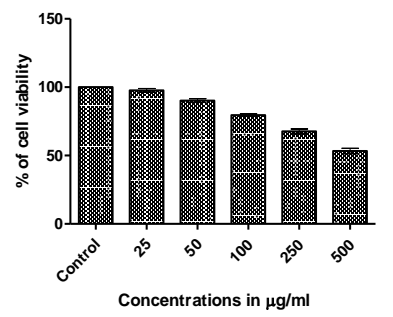

(d)

Fig. 2. (a) DPPH in different concentration (b) FRAP in different concentration (c) NO in different concentration (d) Colon cancer in different concentration

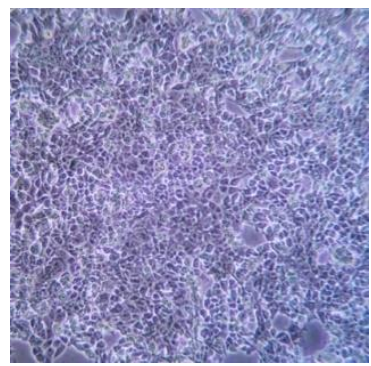

(a)

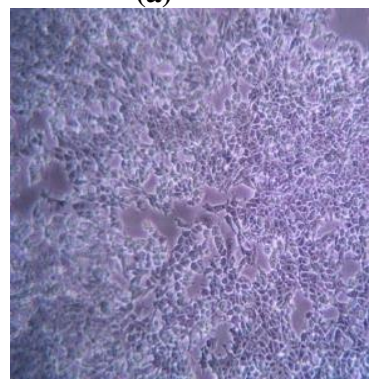

(c)

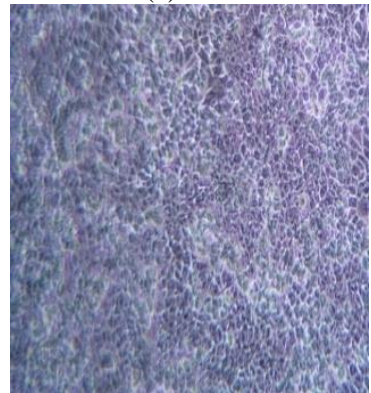

(e)

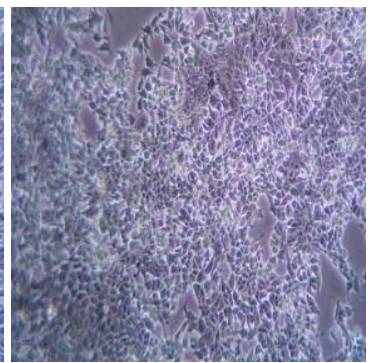

(b)

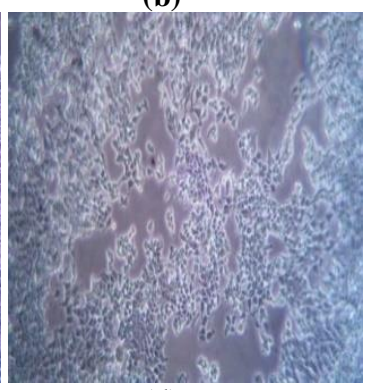

(d)

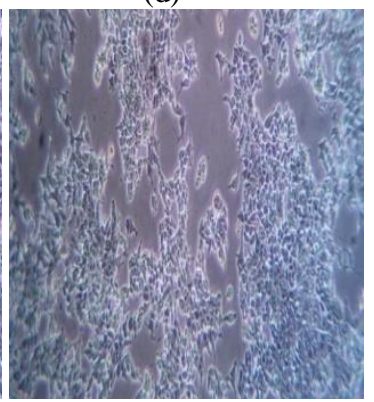

(f)

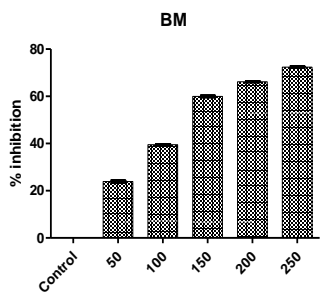

(a)

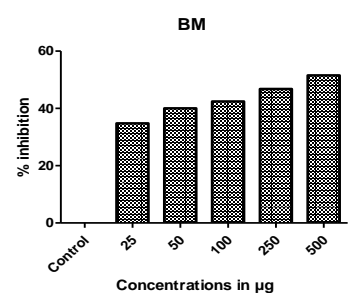

(b)

Fig.3. (a) Colon cancer cell line (a) $25 \mu \mathrm{g} / \mathrm{ml}$ (b) $\mu \mathrm{g} / \mathrm{ml}$ (c) $100 \mu \mathrm{g} / \mathrm{ml}$ (d) $250 \mu \mathrm{g} / \mathrm{ml}$ (e) $500 \mu \mathrm{g} / \mathrm{ml}$ (f) Control

\section{CONCLUSION}

The present study was concluded that the methanolic plant extract of Bacopa monnieri having a high potential free radical scavenging and anticancer activity due to the presence of phytochemical contents such as alkaloids, 


\section{International Journal of Engineering Applied Sciences and Technology, 2020 Vol. 5, Issue 4, ISSN No. 2455-2143, Pages 300-309 \\ Published Online August 2020 in IJEAST (http://www.ijeast.com)}

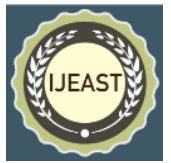

terpenoids, steroid, tannins, flavonoids, phenols, coumarins, quinons and glycosides.

\section{REFERENCE}

[1] M. P. Gupta, P. N. Solis, A. I. Calderon, F. Guionneau-Sinclair, M. Correa, C. Galdames, C. Guerra, A. Espinosa, G. I. Alvenda, G. Robles and R. Ocampo, "Medical ethno botany of the Teribes of Bocas del Toro, Panama", J.Ethnopharmacol, vol. 96, pp. 389401, 2005.

[2] D. S. Sandhu and M. Heinrich, "The use of health foods, spices and other botanicals in the Sikh community in London", Phytotherapy Res, vol. 19, 633-42, 2005.

[3] Kalemba. and Kunicka. "Antibacterial and Antifungal Properties of Essential Oils", Curr. Med. Chem, vol. 10, No.10, pp. 813-29, 2003.

[4] K. Abascal and E. Yarnell, "Bacopa for the brain: a smart addition to western medicine", Altern. Complement. Ther, vol. 17, pp. 21-25, 2011.

[5] C. Calabrease, W. L. Gregory and M. Leo, Effects of a standardized Bacopa monnieri extract on cognitive performance, anxiety, and depression in the elderly: A randomized, double-blind, placebo-controlled trial. $J$ Altern Complement Med. 14:707-713. 2008.

[6] A. Morgan, J. Stevens and Does, "Bacopa monnieri improve memory performance in older persons? Results of a randomized, placebocontrolled, double-blind trial", $J$ Altern Complement Med, vol. 16, pp. 753-759, 2010.

[7] R. N. Chopra, S. L. Nayar and J. C. Chopra, "Glossory of Indian Medicinal plants", CSIR, New Delhi, India, 1956.

[8] P. Jain, N. K. Khanna, N. Trehan, V. K. Pendse and J. L. Godhwani, "Anti-inflammatory effects of an Ayurvedic preparations Brahmi Rasayana, in rodents", Ind. J. Exp. Biol, vol. 32, pp. 633636, 1994.

[9] V. Elangovan, S. Govindasamy, N. Ramamoorthy and K. Balasubramanian, "In Vitro Studies on the anticancer activity of Bacopa monnieri", Fitoterapia, vol. 66, pp. 211-215, 1995.

[10] Y. B. Tripathi, S. Chaurasia, E. Tripathi, A. Upadhyay and G. P. Dubey, "Bacopa monniera Linn.as an antioxidant: mechanism of action", Indian J. Exp, vol. 34, pp. 523-526, 1996.

[11] S. B. Vohora, T. Khanna, M. Athar and B. Ahmad, B. "Analgesic activity of bacosine, a new triterpene isolated from Bacopa monnieri", Fitoterapia, vol. 68, pp. 361-365, 1997.

[12] S. Sinha and P. Chandra, 1990. "Removal of $\mathrm{Cu}$ and Cd from water by Bacopa monnieri (L.)", Water Air Soil Pollut, vol. 51, pp. 271-276, 1990.

[13] S. Sinha, M. Gupta and P. Chandra, "Bioaccumulation and biochemical effect of mercury in the plant Bacopa monneri (L.)", Environ. Toxicol. Wat. Qual, vol. 11, pp. 105112, 1996.

[14] S. Sinha, "Accumulation of $\mathrm{Cu}, \mathrm{Cd}, \mathrm{Cr}, \mathrm{Mn}$, and $\mathrm{Pb}$ from artificially contaminated soil by Bacopa monnieri", Environ. Monit. Assess, vol. 57, pp. 253-264, 1999.

[15] S. Yadav, O. P. Sukla and U. N. Rai, "Chromium pollution and bioremediation", Environ. News Archiv, vol. 11, pp. 1-4, 2005.

[16] K. R. Khandelwal, K.R. "Practical pharmacognosy techniques and experiments. 19th ed. New Delhi: NiraliPrakashan", Nitnth edition, vol. 23, pp. 10-23, 2002.

[17] J. Lin, A. R. Opoku, M. Geheeb-Keller, A. D. Hutchings, S. E. Terblanche, A. K. Jager and J. Van Staden, "Preliminary screening of some traditional Zulu medicinal plants for antiinflammatory and anti-microbial activities", Journal of Ethnopharmacology, vol. 68, pp. 267-274, 1999.

[18] N. Raman, "Phytochemical Technique", New Indian Publishing Agencies, New Delhi, pp.19, 2006.

[19] M. S. Blois, "Antioxidant determinations by the use of a stable free radical", Nature, vol. 26, pp. 1199-1200, 1958.

[20] S. Dudonne, X. Vitrac, P. Coutiere, M. Woillez and J. M. Merillon, "Comparative study of antioxidant properties and total phenolic content of 30 plant extracts of industrial interest using DPPH, ABTS, FRAP, SOD, and ORAC assays", Journal of Agricultural and Food Chemistry, vol. 57, pp. 1768-1774, 2009.

[21] S, Luqman, S. Srivastava, R. Kumar, A. K. Maurya and D. Chanda, 2012. "Experimental assessment of Moringa oleifera leaf and fruit for its antistress, antioxidant, and scavenging potential using in vitro and in vivo assays," Evidence-Based Complementary and Alternative Medicine, Article ID 519084.

[22] L. C. Green, D. A. Wagner, J. Glogowski, P. L. Skipper, J. S. Wishnok and S. R. Tannenbaum, "Analysis of nitrate, nitrite and $[15 \mathrm{~N}]$ nitrate in biological fluids", Anal. Biochem, vol. 126, pp. 131-138, 1982. 


\section{International Journal of Engineering Applied Sciences and Technology, 2020 \\ Vol. 5, Issue 4, ISSN No. 2455-2143, Pages 300-309 \\ Published Online August 2020 in IJEAST (http://www.ijeast.com)}

[23] U. K. P. R. Karunaratne and M. M. S. C. Karunaratne, "Evaluation of Methanol, Ethanol and Acetone extracts of four plant species as repellents against Callosobruchus maculatus (Fab.)", Vidyodaya J. of Sci, vol. 17, pp. 1-8, 2012.

[24] L. Thanh Van Ngo, J. S. Christopher, C. B. Michael, D. N. Phuong, and V. V. Quan, "Impact of Different Extraction Solvents on Bioactive Compounds and Antioxidant Capacity from the Root of Salacia chinensis", Journal of Food Quality, pp. 1-8, 2017.

[25] I. D. Bhatt, R. Sandeep and S. R. Ranbeer, "Antioxidants in Medicinal Plants", Biotechnology for Medicinal Plants, pp. 295326, 2013.

[26] M. Saxena, J. Saxena and A. Pradhan, "Flavonoids and phenolic acids as antioxidants in plants and human health", International Journal of Pharmaceutical Sciences Review and Research, vol. 16, No. 2, pp. 130-134 2012.

[27] A. Siddhuraju and K. Becker, The antioxidant and free radical scavenging activities of processe d cowpea (Vigna unguiculata (L.) Walp.) seed ext racts", Food Chem, vol. 101, No. 10-19, 2007.

[28] G. R. Beecher, "Overview of dietary flavonoids: nomenclature, occurrence and intake", J. Nutr, vol. 133, No. 10, pp. 324832542003.

[29] R. Gul, S. U. Jan, S. Faridullah, S. Sherani and N. Jahan, "Preliminary Phytochemical Screening, Quantitative Analysis of Alkaloids, and Antioxidant Activity of Crude Plant Extracts from Ephedra intermedia Indigenous to Balochistan", The ScientificWorld Journal, pp. 1-7, 2017.

[30] K. Santhi and R. Sengottuvel, R, "Qualitative and Quantitative Phytochemical analysis of Moringa concanensis Nimmo", Int.J.Curr.Microbiol.App.Sci, vol. 5, No. 1, pp. 633-640, 2016.

[31] F. N. Ekwueme, O. F. C. Nwodo, P. E. Joshua, C. Nkwocha and P. E. Eluka, "Qualitative and Quantitative Phytochemical Screening of the Aqueous Leaf Extract of Senna mimosoides : Its Effect in in vivo Leukocyte mobilization induced by inflammatory stimulus", International Journal of Current Microbiology and Applied Sciences, vol. 4, No. 5, 1176-1188, 2015.

[32] S. Sreeja and K. Regi Raphael, "Qualitative and quantitative phytochemical analysis and DPPH radical scavenging activity of different extracts of flower of Bauhinia acuminata linn",
International Journal of Current Pharmaceutical Research, vol. 9, No. 6, pp. 2326, 2017

[33] M. Janarthanan and M. Senthil Kumar, "Qualitative and Quantitative Analysis of Phytochemical Studies on Selected Seaweeds Acanthopora Spicifera and Sargassum Wightii". International Journal of Engineering Research and Development, vol. 7, pp. 11-15, 2013.

[34] D. Mohammed, T. Elkatony and F. Ward, "Qualitative and Quantitative Analysis of Phytochemical Studies on Brown Seaweed, Dictyota dichotoma", International Journal of Engineering Development and Research, vol. 4, No. 2, 674-678, 2016.

[35] S. Mohamed Edrah, A. Aljenkawi, A. Omeman F. Alafid. "Qualitative and quantities analysis of phytochemicals of various extract for Ephedra altissima from Libya",. Journal of Medicinal Plants Studies, vol. 4, No. 3, pp. 119121, 2016.

[36] R. M. Prabhavathi, M. P. Prasad and M. Jayaramu, "Studies on Qualitative and Quantitative Phytochemical Analysis of Cissus quadrangularis", Adv. Appl. Sci. Res, vol. 7, No. 4, pp. 11-17, 2016.

[37] C. D. Porto, S. Calligaris, E. Celloti and M. C. Nicoli, "Antiradical properties of commercial cognacs assessed by the DPPH test", J. Agric. Food Chem, vol. 48, pp. :4241-4245, 2000.

[38] J. R. Soares, T. C. P. Dins, A. P. Cunha and L. M. Almeida, "Antioxidant activity of some extracts of Thymus zygis", Free Radic. Res, vol. 26, pp. 469-478, 1997.

[39] S. Arora and D. Kumar, "Shiba. phytochemical, antimicrobial and antioxidant activities of methanol extract of leaves and flowers of Ipomoea cairica", International journal of pharmacy and pharmaceutical sciences, vol. 5, No. 1, pp. 198-202, 2013.

[40] H. Lata and G. K. Ahuja, "Role of free radicals in health and disease", Ind. J. Physiol. Allied Sci, vol. 57, pp. 124-28, 2003.

[41] R. Ross, "The pathogenesis of atherosclerosis: a perspective for the 1990's", Nature, vol. 362, pp. 801, 1993.

[42] B. L. Halvorsen, M. H. Carlsen, K. M. Phillips, S. K. Bohn, K. Holte, D. R. Jacobs Jr and R. Blomhoff,. "Content of redox-active compounds (ie, antioxidants) in foods consumed in the United States", Am. J. Clin. Nutr, vol. 84, pp. 95-135, 2006.

[43] N. Pellegrini, M. Serafini, B. Colombi, D. D. Rio, S. Salvatore, M. Bianchi and F. Brighenti, "Total antioxidant capacity of plant foods, 
beverages and oils consumed in Italy assessed by three different in vitro assays", J. Nutr, vol. 133, pp. 2812-2819, 2003.

[44] M. Bejeli, V. Rowshan and A. Zakerin, "Comparison of total Phenolic content and antioxidant activity of five Salvia species by FRAP and DPPH assay", Int J Pharm Pharm Sci Acad Sci, vol. 4, pp. 572-575, 2012.

[45] I. Turan, S. Demir, K. Kilinc, S. O. aman, S. Misir, H. Kara and O. Deger, "Cytotoxic effect of Rosa canina extract on human colon cancer cells through repression of telomerase expression", Journal of Pharmaceutical Analysis, 2017.

[46] S. Gothai, K. Muniandy, N. Mohd Esa, S. K. Subbiah and P. Arulselvan, "Anticancer potential of Alternanthera sessilis extract on HT29 human colon cancer cells", Asian Pac J Trop Biomed, vol. 8, pp. 394-402, 2018. 